\title{
Chapter 4. The Contested Landscapes of Myth and History in Tana Toraja
}

\section{Roxana Waterson}

In the English language "landscape" is a word that comes, as Olvig (1993:308) reminds us, with many layers of "concealed, congealed meanings", but having a predominant association with the visual, specifically with the idea of topography as seen from a particular viewpoint; its original seventeenth century sense was of a painting of natural scenery, only subsequently of the vista itself, or of the landforms of a particular area. For anthropologists the effort to comprehend an unfamiliar way of life leads to a different kind of concern with landscape: an attempt to understand the involvement of people with the land that over time has generated a "sense of place" for them. ${ }^{1}$ This sense of place may be derived from many things. In hunter-gatherer societies, a powerful sense of place is commonly derived from interacting with the land, from living in it and off it, and bringing it alive through myth and ritual performance, without the need to effect alterations by means of architecture or construction. Other landscapes, even if perceived to be "natural", are in fact transformed and moulded by centuries of intensive human use and changing agricultural practice (Hoskins 1956). The visual perspective is thus only one among many possible dimensions by which a landscape can be known and comprehended. Moreover, as various authors note (for example, Bender's discussion of Stonehenge in Britain [1993]), meanings may not only be constantly revised over time, but may be contested, more or less fiercely, by those with different interests at any particular historical moment.

My own concern with questions of landscape and identity derives from my fieldwork among the Sa'dan Toraja of Sulawesi. ${ }^{2}$ The Toraja occupy the highlands of the province of South Sulawesi, in the kabupaten or sub-provincial district of Tana Toraja, whose population according to the census of 1990 is around 370,000. Many Toraja today also live outside of this region, having migrated to cities or to other parts of Indonesia in search of work or higher education. The majority of Toraja today are Christian. Most of them are members of Gereja Toraja, the Toraja Church, which is Calvinist, though there is also a minority of Catholics and adherents to a variety of more recently arrived sects including Seventh Day Adventists, Pentecostalists, Baptists and others. The indigenous religion, now known as Aluk to Dolo or "Way of the Ancestors", won official recognition from the Indonesian government in 1969, remaining one of the few indigenous religions to have done so. However, since that time the decline in its following has been rapid, only accelerating over the past decade. 
According to 1990 census figures, its adherents now constitute a mere ten per cent of the population; most of these are older people and those living in the remoter districts. Knowledge of myths of origin and details of oral history has never been evenly distributed, but interest in these matters has not entirely died away, because of their continued political significance in relation to claims of precedence in the present (Waterson 1992). It is these questions of precedence that I shall principally address in this paper. The interweaving of genealogy and place names, which are also the sites of origin houses (tongkonan), have a bearing on present-day claims to status. They provide one illustration of the themes of precedence and topogeny developed by Fox in this volume and elsewhere (Fox 1994, 1995).

\section{Houses, Myths and Genealogies in the Toraja Landscape}

The Toraja landscape is a mountainous one of great natural beauty. This landscape is imbued with meaning partly through the Aluk to Dolo, which, like most indigenous religions of small-scale societies, is characteristically animist and highly localized, being intimately linked with the context in which it has evolved. Aluk populates the natural world with deata - deities or nature spirits - and attributes to the ancestors, whose rock graves dot the landscape, a close familiar presence and a continued concern with the fertility of the land and of their living descendants who work it. Features of the landscape such as mountains and rivers have a place in myths and oral histories, especially the genealogies and accounts attached to particular noble origin-houses. Some of these myths tell of founding ancestral couples described as to manurun di langi' (ones who descended from the sky) and to kendek diomai liku (ones who rose out of a pool), of whom the man is said to have descended from the sky on to a mountain top, and married a woman who rose out of a river pool. These supernatural ancestors give prestige to the houses they founded, which in the past were the locus of political power, their occupants exercising control over local villages or groups of villages. The houses themselves were visibly magnificent, with their huge roofs and rich carving, contrasting with the simple bamboo houses built by commoners. Periodically they would serve even more dramatically as centres of power, whenever they became the sites for the enactment of elaborate rituals, which validated and reinforced the status of aristocratic families, while simultaneously becoming a part of the house's ongoing history. 


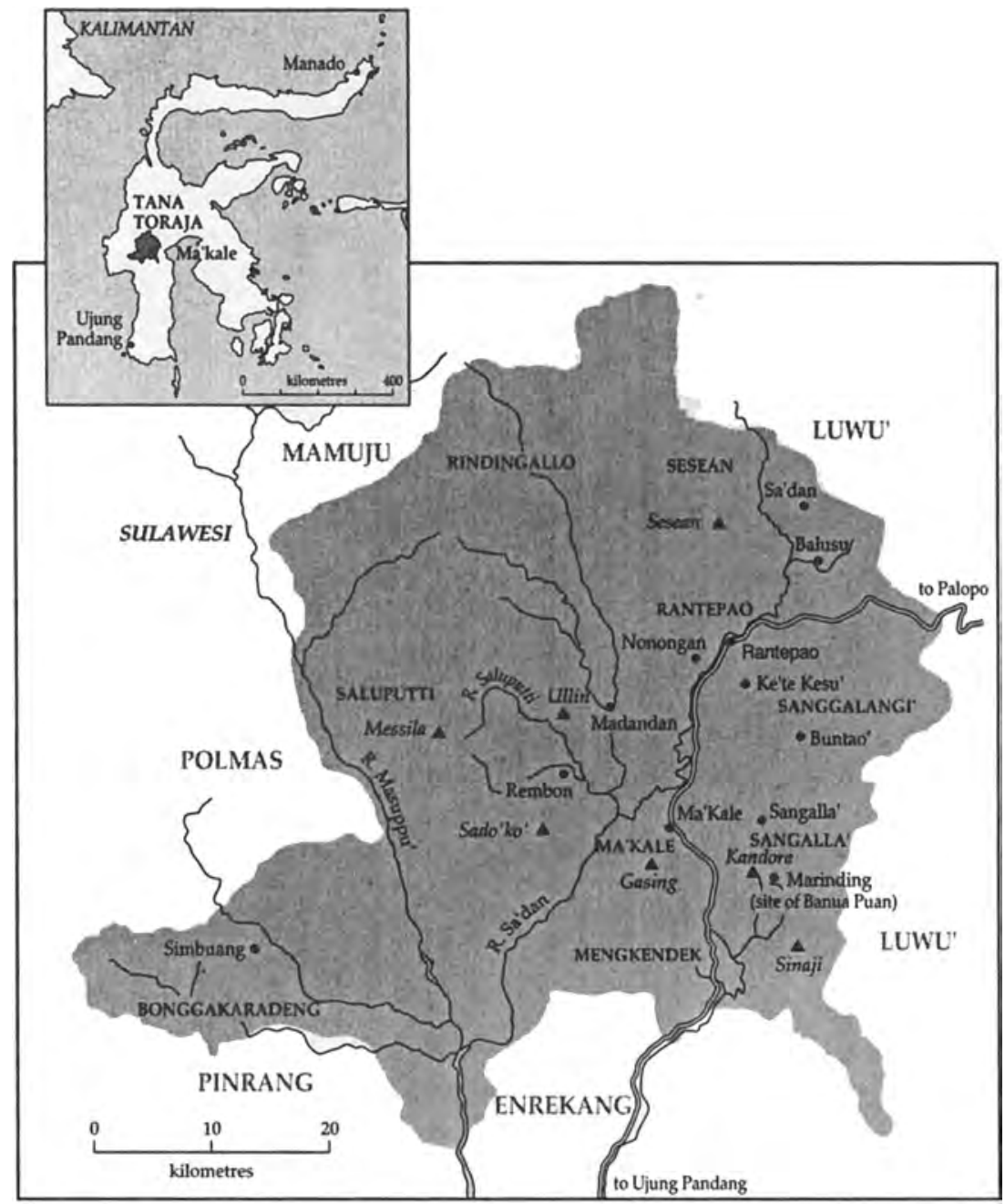

\section{Map of Tana Toraja}

In Tana Toraja, houses, genealogies, myths and histories are all closely bound up together and embedded in local landscapes. Houses are the major points of reference within the bilateral kinship system. People trace their descent equally from houses on both sides of the family, where their parents, grandparents, or more distant ancestors were born. At the birth of a child, the father buries the afterbirth on the east side of the house, so that over time, the house becomes the place where "many placentae are buried", and thus should never be moved. Some origin-houses associated with very important ancestors have in fact long ceased to exist, but their sites are still well remembered and in theory if the descendants willed it, they could be rebuilt. These houses have genealogies with a depth of between twenty and thirty generations, and many people in Toraja 
can ultimately trace descent back to them. When people recount such genealogies, they tell who married whom, who were their children, and where those children then moved to in order to found new "branch" houses of their own. Founding and branch houses are sometimes characterized as "mother" and "child" (indo'na/anakna); sometimes, in a botanical metaphor familiar from many other Indonesian societies, as "trunk" and "branch" (garonto'/tangke), or the original founding house may be termed ongi'na (ongi: stem, as in the stem of a fruit); when demonstrating this idea, one informant picked up a mangosteen, another a coconut, pointing out how "the whole fruit grows from the stem". ${ }^{3}$ The house sites form a sort of network, providing what is as much a geographical as a historical account of the settlement of the Toraja landscape, as people spread out to cultivate new areas. Possibly the most widely acknowledged and important site of all is Banua Puan, in Mengkendek, where the ancestor Tangdilino' is said to have built the first carved tongkonan to have been consecrated with rituals. ${ }^{4}$ Tangdilino' was not a to manurun, but was one of the earliest Toraja ancestors - in one genealogy I collected, he is shown as two, in another as eight, generations removed from the first human couple on earth. The site at Banua Puan is well remembered, though it has not had a house on it for centuries; it is still vacant, and has been kept clear by local Mengkendek descendants, although a church has been built close beside it. Most noble houses all over Tana Toraja can trace some link to Banua Puan; one informant, Pak Kila' (a member of the Parandangan $A d a^{\prime}$, an association of representatives of the Aluk to Dolo), described it as the penggarontosan (from garonto': base, trunk) - the original tongkonan from which all others derive. Even though no material structure has existed here for so long, Banua Puan has kept a vital place in oral memory.

The idea of the house as a substitute for written history was made explicit to me by one noble informant, Tandiruru of Alang-Alang. Unlike their neighbours of the Bugis and Makasar lowland kingdoms, Toraja never developed a written script of their own. But instead of the written chronicles which the Bugis and Makasar peoples recorded on strips of palm leaf (lontara'), Torajans, he pointed out, had the tongkonan. "History" here, as everywhere, serves particular purposes. It is a prerogative of the aristocracy, who were the only ones permitted to build elaborately carved houses, and the only ones with an interest in remembering long genealogies. Many of these genealogies contain the names of the protagonists of well-known mythical stories. Objects associated with some of these characters are preserved as powerful heirlooms inside the houses with which they are associated. Tongkonan and genealogy, used in the past as legitimating devices by the aristocracy, are still relevant today as the nobility of different areas compete with each other. Now the arena is one not simply of local but of national politics, and a newly commercializing economy. Those areas that can most convincingly present themselves as richest in "authentic" Toraja history and culture are in a better position to lay claim to a share of tourism 
development funds, to be used for the maintenance or renewal of origin-houses and the improvement of infrastructure such as roads. They may then look forward to an increasing number of wealthy foreign visitors passing through. Mythical ancestors and events, and finely carved houses to go with them, remain an essential ingredient of these contested histories.

\section{Houses and Their Myths: Connections With Lowland Kingdoms}

Some myths told in relation to the founding of particular houses also serve to situate Toraja in relation to their neighbours, the Bugis and Makasar peoples of the South Sulawesi lowlands. Several provide grounds for claiming precedence over what were objectively the much more powerful centralized and Islamicized kingdoms of South Sulawesi. The royal families of these kingdoms have intermarried with the Toraja nobility of certain areas over a long period, and indeed acknowledge their links to a Toraja ancestor, Laki Padada. Laki Padada is represented in several genealogies as a grandson of Tamboro Langi', one of Toraja's most famous to manurun. His father Puang Sanda Boro married a woman whom he discovered inside a bamboo; she was called To Bu'tu ri Pattung (One who Appeared from a Bamboo) or Puang Ao' Gading (Lady of the Bamboo). She gave birth to two children, a son, Laki Padada, and a daughter, Puang Mate Mangura or Puang Mate Malolo (both names mean Lady who Died Young). Distraught at his sister's death, Laki Padada vowed to travel the world in search of the secret of eternal life. His journeys eventually brought him to the Makasarese kingdom of Goa. ${ }^{5}$ Here after many adventures he married the ruler's daughter. Of their three sons, one, Pattala Merang, became the ruler of Goa; the second, Pattala Bunga, became the ruler of Luwu', while the third, Pattala Bantan, returned to Toraja and married Petimba Bulaan (Golden Dipper), variously depicted as the daughter or granddaughter of Manaek, founder of tongkonan Nonongan in Sanggalangi' district. Pattala Bantan went to Sangalla' and ruled over that part of Toraja known as the Tallu Lembangna or Three Districts of Ma'kale, Sangalla' and Mengkendek. These southern districts formed a federation, the closest Toraja ever came to emulating the centralized kingdoms of the lowlands. Later descendants of Laki Padada are said to have married into the royal family of Bone. These links are still acknowledged by the royal families of these lowland kingdoms, who have maintained a long tradition of intermarriage with Toraja nobility. ${ }^{6}$

Other tales recount how a Toraja "trickster" manages to outwit the Datu (ruler) of Luwu'. ${ }^{7}$ The tendency of these stories is to downplay the extent of Toraja subservience to Luwu' (regions closest to the borders of Luwu' paid some customary tribute as a sign of respect and in recognition of marriage ties, without, it seems, expecting any interference in their affairs), or even to claim a degree of precedence over Luwu'. One recurring theme concerns a hero, known in 
variants I collected in the Kesu' area as Tali Siba'ba, whose mother is a wild pig. He weds the female Datu of Luwu' and secretly installs his mother in the attic of the palace, forbidding the local populace to eat pork out of deference to her; this is claimed to account for why the people of Luwu' (who have been Muslim since the early seventeenth century) do not eat pork. In one version, the hero ends by changing his name to Karaenge Dua (Twice Noble), having become a noble of Luwu' as well as Toraja. An almost identical tale concerns the sons of Bonggakaradeng, a blacksmith who has given his name to the most westerly present-day kecamatan (district) of Tana Toraja; but in this case the story concerns relations with the Bugis area of Sawitto (present-day Pinrang), which borders on West Toraja and with which the Toraja regions of Bonggakaradeng and Simbuang have historically had close connections. ${ }^{8}$ Bonggakaradeng came from a village called Batu Tandung, near the Masuppu River. He was another person who found his wife inside a bamboo; her name was Datu Baringan, and she had a sister who was a python. Once while out in the forest on a hunting trip, Bonggakaradeng stopped to rest beneath an uru tree at a place called Pokka Uru on Buttu Karua (a mountain in Simbuang). He urinated on a fallen tree, unaware that in doing so, he had impregnated a spirit pig inside the tree. The pig gave birth to twin boys, Buttu Karua and Buttu Layuk. When they were about six years old, the mother sent them to look for their father, and they came to where Bonggakaradeng was working in his forge. They offered to help him in the forge, but he refused, not seeing how they could be of any use to him. But while he was eating his lunch in the house, they finished all his work for him, and to a standard exceeding his own. According to another version, they made a sword of gold (la'bo' penai bulawan) called Tonapa. This sword became a famous heirloom whose sheath is still kept in Sawitto, while the blade is in Simbuang. ${ }^{9}$ Eventually they persuaded the astonished Bonggakaradeng that he was indeed their father, and lived with him for a time, but, offended by his persistence in eating pork, they set off again by boat down the Masuppu River, taking their mother with them, until they reached Sawitto, where the pig-mother eventually turned into stone. ${ }^{10}$ They made magic there, causing the sky to go dark except around their own house, until the local people begged for an explanation. The brothers told them that they would bring back the sunlight if the people would agree henceforth always to show them various marks of respect, and to abstain from eating pork or the meat of any animal that died without being slaughtered. Thus the Bonenese became Muslim, while the two brothers married the daughters of a great aristocratic family, and had several children who became important ancestors in their turn. This is one of several tales told in justification of a saying in Simbuang: nene' Simbuang, appo Sawitto, or "Simbuang is the grandfather and Sawitto is the grandchild". Clearly this is an attempt to assert precedence over Sawitto, interesting because, just as in the case of Toraja-Luwu' relations, objectively Sawitto was a more powerful kingdom. According to Bigalke 
(1981:25), from the seventeenth to nineteenth centuries Simbuang was drawn into a tributary relationship to this small state; the Dutch, however, terminated this relationship by incorporating Simbuang into the administrative subdivision of Ma'kale as a means of punishing Sawitto for its heavy resistance to Dutch forces.

In Sa'dan and Balusu, areas of northeast Toraja bordering on Luwu', a different story is told about an unusual hero from Sa'dan named Bulu Nanga (Hairy Penis). Bulu Nanga once travelled with a party of his followers and slaves to purchase buffaloes and salt in Palopo. The attendants of the Datu of Luwu' saw him bathing in the river and, catching sight of his remarkable appendage, made a report to the Datu. Bulu Nanga married the Datu's daughter, and his sword, called La Karurung, is said to be still kept in the palace at Palopo. Although these stories were no doubt told largely for local benefit, reference to myth can still be useful on occasion in interactions with lowlanders; an acquaintance recounted how on a visit to the provincial capital of Ujung Pandang, an elderly Toraja priest (to minaa), on meeting a Bugis government official, impressed the latter with his genealogical inquiries, by means of which he quickly established that the official must be the descendant of a mythical Toraja ancestor! $^{11}$

While these tales establish Bugis descent from Toraja heroes, some Toraja noble houses conversely claim descent from Bugis heroes. An example is Sawerigading, father of La Galigo, whose many adventures are recorded in the Bugis epic cycle of I La Galigo and known throughout Sulawesi (Kern 1989; Andi Zainal Abidin 1974). Such legitimating claims are made chiefly by the aristocracies of the districts adjoining Luwu', who have historically had, and still have, more contact with the former kingdom through intermarriage. I encountered examples both from Sa'dan and Balusu in the northeast, and from the southern federation of Ma'kale, Mengkendek and Sangalla'. A descendant of tongkonan Galugu Dua in Sa'dan district provided me with a written genealogy of sixteen generations, the founding figure of which is Andi Tendriabeng (Bug.: We Tendriabeng), Sawerigading's sister, shown as having married one Ramman di Langi' of tongkonan Punti in Sesean. ${ }^{12}$ Like other genealogies, this one includes the names of many other tongkonan founded by the descendants of this original couple. Five generations later, two brothers, both called Galugu (hence the present name of the settlement, Galugu Dua, meaning Two Galugus), are said to have been among the "Ancestors of the Same Dream" (Nene' Pada Tindo) who "held back the mountain of Bone" (untulak buntuna Bone), or resisted an invasion supposedly mounted by the ruler of Bone, Arung Palakka, in the mid-seventeenth century. ${ }^{13}$ Further south, I collected versions of the Sawerigading story from Tato' Dena' of Mandetek in Ma'kale - the To Minaa Sando or leading priest of the Aluk To Dolo; and from an elderly blind storyteller, Indo' Somba, of Kandora in 
Mengkendek - who was one of several informants providing detailed accounts to Salombe' (1975). Kandora seems to have established for itself a particularly strong association with Sawerigading, for a special "house" in the form of a rice-barn here at Potok Tengan contains stones, treasured as powerful heirlooms, which are said to be the petrified remains of La Pindakati of Cina, Sawerigading's first wife. ${ }^{14}$ The stones were brought here by La Pindakati's daughter Jamanlomo or Jamallomo, who married Puang Samang of Gasing (a mountain in Ma'kale district). In Salombe"s account, it is stressed that Jamallomo, being a descendant of Batara Guru, could only wed a man who was also a descendant of a to manurung or one descended from the heavens. Puang Samang, being a descendant of the Toraja to manurun Tamboro Langi', claimed in this region to have descended on Mount Kandora, proved an acceptable suitor. Jamallomo returned with him to Toraja, where they founded tongkonan Dulang at Potok Tengan (Salombe' 1975:276-277). A notable feature of the account given by Salombe' is the naming of particular places connected to the travels and deeds of the protagonists, names which survive to the present day. A place with a large mango tree is still called pao (mango), for example, while a spot where buffaloes were bathed is still called pa'burasan (place of foam) (Salombe' 1975:275). A local landscape is in this way given meaning in a manner familiar to us from many other societies. ${ }^{15}$

\section{Sky Men and Water Women: The to Manurun Ancestors}

In Tana Toraja, the idea of the to manurun, mythical beings who descended from the heavens on mountain tops and became local rulers, may have been borrowed from the Bugis, where legends of supernatural beings, the to manurung, are recounted in court chronicles, and are regarded by Noorduyn (1965) and Mattulada (1978) as having performed a legitimating function in the formation of lowland kingdoms during the thirteenth century. Toraja to manurun are always paired with an equally supernatural spouse, a woman who rose out of a river pool. People all over Toraja can trace their descent from one or another of these ancestors, though they appear to feature most prominently in southern, central and western areas. It is between these areas that competition over ancestors today appears to be keenest. The central Kesu' area claims To Manurun Puang ri Kesu' (Lord of Kesu) as its most important founding ancestor, while in the southern "Three States" (Tallu Lembangna), Tamboro Langi' is more important. The nobles in these two areas are far more status-conscious and had enjoyed more concentrated power in the past than those of the west, a region known for its egalitarian forms of address and more neighbourly ethos. Nobles from the two former districts would often express scorn at the idea of any significant ancestors coming from the west, although westerners disagree, and are anxious to gain more recognition for their own claims. A specific dispute concerns which particular mountain was the site on which Tamboro Langi' descended. According to traditions in the west, he landed on top of Ullin, a peak in Banga district, and 
founded a house there with his wife, Sanda Bilik, who rose out of a pool at the confluence of the Sa'dan and Saluputti Rivers. Ullin is also particularly associated with the deata, nature deities, who are said to congregate there annually after the harvest. Members of the southern states, however, tend to claim that Tamboro Langi' descended not at Ullin, in the west, but on Kandora, a dramatic peak that thrusts from the valley floor in Ma'kale district. Some versions say he later moved to Ullin, others that he lived only on Kandora and never went near the west at all.

Important houses in each area have their own stories about important ancestors and supernatural occurrences. The following examples were gathered in the westerly Saluputti region, particularly desa Malimbong, where I lived during my initial fieldwork. Ullin forms a triangle with two other mountain peaks visible from Malimbong: Sado'ko' and Messila. Next to Tamboro Langi' of Ullin, probably the most important ancestor in Saluputti genealogies is Gonggang Sado'ko', who is said to have descended on Sado'ko' and married a pool-woman, Marrin di Liku. In one account Gonggang is claimed to be the first human on earth in western Toraja, and is credited with sixteen children, some of whom bear the names of deities in the Toraja pantheon. The late Mangesa', former Kepala Desa of Malimbong (1965-71), who reckoned himself an eleventh-generation descendant of Gonggang, maintained that owing to his supernatural qualities, Gonggang enjoyed great longevity and was still alive at the time of Arung Palakka's invasion of Toraja, in the resistance to which, in Mangesa"s account, he played a leading role. But in the rather patchy genealogies that I collected from some present-day inhabitants of Ullin, he featured not as a to manurun at all, but as the grandson of Tamboro Langi'. The third mountain, Messila, is also associated with a to manurun, Kila' Ta'pa ri Ba'tang (Lightning Striking a Tree). Little is known about this ancestor, but according to Isaak Tandirerung, former District Head of Ulusalu, he descended somewhat later than Tamboro Langi'. He married a pool-woman and founded a house on Messila (which no longer exists), and their descendants later founded Pattan, the tongkonan layuk or "great house" of Ulusalu, from which Isaak himself was descended. In all three cases we find the same identification between the mountain and the mythical and long-vanished origin-house.

In desa Malimbong at the time of Dutch takeover, there were two rival noble families whose main origin-houses were at Pasang and Pokko', near Sawangan. Pasang's genealogy commences with Gonggang Sado'ko', Pokko"s with another remarkable ancestor, Pa'doran. Descendants of these two houses tended to magnify the importance of their own ancestor, while deriding stories about the other. Pa' doran is said to have been born two generations or so after Gonggang, but also to have commanded Gonggang's army in the war against Bone. He was not a to manurun, but a to mendeata, for he had received powers from the deities (deata) in a dream. He could walk several miles in a single step and had unnatural 
strength. If he stood on Sado'ko', he could reach Messila in a single stride, and with a third stand upon Ullin. He was held in awe, and like Gonggang, is said to have organized the people in matters relating to agriculture, warfare, adat and religion.

Several tales about $\mathrm{Pa}^{\prime}$ doran are related to local features of the landscape. Everything he said came to pass. When he said, "My buffalo is big", it at once became enormous, and when he said, "It will make a mountain with its horns", the buffalo tossed its head and ploughed two great furrows with its horns. The hill thus thrown up between them is called Buttu Susu, still a landmark in Malimbong. In another version, the tossing of the buffalo's horns threw up three villages - Buttu Susu, Bea and Matande; its droppings formed the mountain called Gattungan, near Buttu Susu. Pa' doran never married. He disliked the idea of rotting at death, and instead instructed his family to make a special basket for him. He then climbed into it and turned into stone. This basket is still stored in the tongkonan at Pokko', and can be viewed only if the appropriate offerings are made. The inhabitants claim that when an earth tremor is felt here, it means that $\mathrm{Pa}^{\prime}$ doran is descending from his basket to go out for a walk, and then a rattling as of coins can be heard inside the house.

One other to manurun in Malimbong was associated with the tongkonan at Parinding in Sa'tandung. Batotoilangi' (Appearing from the Sky) married a woman called Mandalan i Limbong (Deep in the Pool), who rose up out of a natural spring, which is still used as a water source today by the villagers of Parinding. They had eight children. One day, Batotoilangi' was offended by the smell of someone roasting dog meat, and returned to the sky, while his wife went back to her pool. Various taboos are associated with the house, not only on the eating of dog meat, but also of rat (field rats are occasionally consumed in some parts of Toraja), snails, or meat from funerals. It was also forbidden to spit on the site of the house. This founding couple, according to the inhabitants of the house, lived about eleven generations ago, at about the same time as Gonggang Sado'ko'. Before leaving, Batotoilangi' told the people that they would know he was still around when they heard thunder or when it rained. If ever a chicken is sacrificed here, even in the dry season, it is said that a light shower will fall. When there is a rainbow, it always appears with one end on the site of the original house, stretching over the banyan tree which grows beside it. If descendants of the house see a rainbow after making offerings, this is taken to mean that Batotoilangi' and the deata have received it. In the past, the house had many slaves attached to it, who all lived at the bottom of the hill on which it stood.

It is not hard to see how all these myths and stories, woven into the genealogies of politically powerful noble houses, served to elevate and justify the status of their inhabitants. The possession of powerful heirlooms connected 
to the stories further added to the mystique of these houses (or did, until members of the younger generation yielded to the temptation to sell some of these items to international art dealers). Whether their heroes were once real people, about whom tales were woven, or whether the stories were created first and the names later embedded in genealogies, is impossible to guess. Some, like Pa'doran or Batotoilangi', have highly localized reputations; others such as Tamboro Langi' or Laki Padada, have a fame that spreads more widely and links many descendant houses together. These links are periodically demonstrated and renewed in rites, as when in January 1983, over 100 groups of descendants of the famous tongkonan at Nonongan gathered to celebrate the rebuilding of the house. Not only can many Toraja trace connections to this house and its founder, Manaek, but so can the royal families of Luwu', Goa and Bone, all of whom sent representatives to the ceremony. The Luwu' party even brought a huge pig with them. Through their attendance they acknowledged their descent from Laki Padada, as well as their links through intermarriage with Toraja nobility.

\section{The "Ancestors of the Same Dream": Memories of Bugis Incursions}

The major events of oral history often have a distinctly mythical quality about them. At first I was puzzled by the apparent fusion of history and myth in the accounts I collected, the ability of my informants to engage in heated debate about the details of accounts that to me were clearly mythical, while at the same time infusing accounts of what might be historical events with mythical elements or what appeared to be folk tale motifs. Some informants elided and confused the details of separate historical incidents which happened hundreds of years apart. This, however, appears to be quite typical of social memory in oral societies. ${ }^{16}$ All the same, I would argue that anthropologists need to engage with history as historians understand it, as well as in terms of trying to understand their informants' conceptions of it. Anthropologists have often underestimated how much of the past may be knowable in non-literate societies, though this assumption has been radically changed by more recent studies. In the Toraja case, we are lucky to have the work of a skilled and sensitive historian, Terry Bigalke, to demonstrate just how much of the Toraja past is recoverable (Bigalke 1981). His study provides a most useful bench-mark for examining oral histories in Toraja.

The most prominent events in Toraja oral history again serve to situate Toraja in relation to their more powerful neighbours. They concern various military incursions of the Bugis into the highlands, which were successfully repulsed. The salience of these events has doubtless been heightened in recent times by the recurrence of hostilities during the troubled 1950s, when Bugis forces were twice driven out of Toraja. A "founding moment" seems to have been the struggle against the invading army of a king of Bone, identified in some versions as Arung 
Palakka, who ruled Bone in the late seventeenth century. ${ }^{17}$ In response to this threat, the headmen of Toraja settlements formed an alliance and swore an oath to stand together, the basse lepongan bulan (oath/alliance of the [region] as round as the moon). These leaders are called the Nene' Pada Tindo (Ancestors of the Same Dream) or to pada tindo, to misa' pangimpi (those of the same dream, those of the single destiny). Their short-lived federation is often cited by Toraja as the original source of a "Toraja" identity, but there is no evidence that it gave rise to any long-term political unity, in spite of living on in folk memory. Memories of this event are linked to the landscape in a number of ways, and though similar in form, show considerable local variation in content. They are cast in the form of a dramatic narrative, which tells how a misunderstanding arose between certain Toraja protagonists and the king of Bone. ${ }^{18}$ This gave rise to a battle in which a Toraja warrior, Pakila' Allo, was captured and cruelly tortured by the men of Bone. He however could not be killed, because he had a magic stone (balo') which made him invulnerable to iron. At last he was befriended by the king of Bone, and was given a beautiful lady to be his wife. Returning to Toraja, Pakila' Allo came to live at Randan Batu near Sangalla', where he became a tyrant, who abused and exploited the people, and even his own family, until at length they conspired to murder him. Their eventual success provoked his daughter to carry her complaint to the king of Bone, who sent his forces to extract vengeance from the Toraja. Their excesses in turn caused the "Ancestors of the Same Dream" to form their alliance. In this extraordinary story of cruelty and counter-cruelty, of treachery and betrayal, certain features always recur. One is the focus upon the character of Pakila' Allo, a Toraja who betrays his own people. Another is the idea of a night market, at which crows are sold instead of black cocks, cockatoos instead of white cocks, and a poisonous leaf (lelating) woven into mats which cause the user unexpected irritation. According to some, this market was a means by which the Toraja outwitted the Bugis (an inversion perhaps of the latter's historically dominant commercial role in the highlands); others say the market provided a distraction which prevented the Bugis from noticing the secret meetings of the Ancestors of the Same Dream as they planned their uprising. One person described the market as having been founded by Pakila' Allo himself as a way of enriching himself by attracting people to gamble all night. But a more intriguing explanation was that the market, organized by the Ancestors of the Same Dream, was intended as a warning to the deities, that unless they aided a Toraja victory, their offerings in future would be deliberately muddled up. The third recurrent feature is the description of the Bone troops as a multitude, described as pitu palo-palo (seven helmets). As they assembled for their assault on Toraja, each soldier placed a grain of maize into a large helmet, and they were so many that they filled seven helmets in this manner. Of the seven, only three (or, in some versions, one) of these palo-palo lived to return home after the Toraja uprising. 
The telling of the story always includes a long list of local village leaders (over 100 names in some places), with their places of origin (for example, Karasiak of Madandan), who attended a meeting and swore the oath to defend their homeland. These vary widely in different areas, with a concentration of local names being recalled in each place. Certain hilltops are also recalled as the places where torches were lit to send the signal for the uprising against the Bone troops. The site of the swearing of a "great oath" (basse kasalle) of peace between Bone and Toraja at the end of this war also differs. People in more central districts say that the oath was sworn at Bamba Puang in present-day Enrekang (south of the present border of Tana Toraja), where there is a mountain peak associated with local origin myths. But on a visit to the westernmost district of Simbuang in 1978, I was shown three small standing stones in front of the ancient tongkonan of Simbuang Tua which local residents say mark the spot. ${ }^{19}$ The people of Bone swore that henceforth they would enter Toraja only in peace; the oath curses them if they come in war, and can be ritually "woken up" (ditundan basse) to bring disaster on them if the promise is broken.

Sometimes the list of names and places is recalled without the complete story of events. I recorded one short account of the "Ancestors of the Same Dream" from an elderly to minaa, Saleda of Kinali in Talion, in January 1978. He had begun our interview by telling a creation myth, going on to recount a genealogy which began with a marriage between two ancestors renowned in the western part of Toraja, Gonggang Sado'ko' and Lai' Ullin. ${ }^{20}$ The genealogy comprises a list of descendants who subsequently spread out and travelled to different places in order to found new houses. Saleda then proceeded to explain about the Ancestors of the Same Dream as another important category of ancestors, and the roles they had played in establishing Toraja ritual communities. Rather than a historical account, the names of these ancestors, who "held back the mountain of Bone" (untulak buntuna Bone) in the past, are embedded in a litany which presents them as idealized founding figures, combining political and ritual leadership. It locates them in a sort of Golden Age, reiterating a vision of a time of abundance, when everything flourished and multiplied in response to the celebration of rituals. The account contains no details of the events of the Bone invasion, but rather creates a web of ancestors and the houses and ritual communities which they founded. Part of the text is given below:

Now, this story starts here in our village [region]: [it concerns] Gonggang Sado'ko', the Ancestors of the Same Dream, the Ancestors whom we revere as Lords. Gonggang Sado'ko' held back the mountain of Bone, in the olden days, he stopped their advance into our lands. Then the harvest of the earth flourished and human beings multiplied.

These were the Ancestors of the Same Dream: Pabidang lived at Buakayu; he, the ancestor who dwelt in Buakayu, he too joined in holding back 
the mountain of Bone, in the days gone by. He had responsibility for the [fertility of the] plains and hillsides; the offspring of buffaloes flourished, and human beings were born.

Masuang of Tangsa held back the mountain of Bone, he took care of the plains and hillsides in the days gone by, and everything flourished and was well. He it was.

Amba Bunga' of Ma'kale, Pong Songgo of Limbu, also held back the mountain of Bone in the past. Then the harvest of the earth flourished, people multiplied, everything grew in abundance. These were the Ancestors of the Same Dream, the Ancestors whom we revere as Lords.

Karasiak of Madandan likewise held back the mountain of Bone in the days gone by. He too. And the harvest of the earth was abundant at that time, and human beings multiplied.

Tandi of Lambun held back the mountain of Bone, he who passed down the rules of ritual (sukaran aluk) to the ancestors Sawalinggi and Rangkaianan. The rituals were upheld, and many feasts were celebrated. The merok feast was celebrated, the $b u a^{\prime}$ ceremony was completed.

Pong Manapa' of Bittuang held back the mountain of Bone in the days of the Ancestors revered as Lords. Then the upward-pointing horns [that is, buffaloes] multiplied in the dense forests, and cuscus passing by, and forest monkeys. ${ }^{21}$ Pauang of Malimbong, too, held back the mountain of Bone in the past. The harvests were abundant, nothing at all was wanting ... Those were our Ancestors of the Same Dream, in times past.

The ancestors are presented here as exemplary, not only in their resistance to the Bonenese intrusion but as founders of villages and upholders of ritual. ${ }^{22}$ In his recitation, Saleda greatly abbreviated the list of names, but stressed those who were closely associated with his own region. The network of place names is implicitly linked with the houses founded by noble ancestors in those locations. Just as in the recitation of genealogies, the founding of houses and their locations is woven in with the list of names, and forms an integral part of the information conveyed. The structure of the recitation, with its repetition of set phrases, clearly provides the sort of framework from which a skilled oral poet can generate an account which will be roughly similar though liable to variations on each particular telling. Such variations may not be perceived as relevant, if indeed they can be perceived at all by the performer and his audience. ${ }^{23}$

A second major Bugis incursion that is remembered in Toraja is the war that was fought in the highlands in the 1890s, when the Bugis court of Sidenreng set about trying to wrest control of the lucrative Toraja coffee trade away from the Datu of Luwu'. Instead of the coffee being transported to Luwu"s port at 
Palopo to the east, Sidenreng wanted the trade to flow to its own port at Pare-Pare in the west. Troops from Sidenreng, commanded by Ande Guru, entered Toraja from 1885 with some support from certain Toraja chiefs who saw their own interest in defying Luwu', and over the next ten years were largely successful in diverting the coffee trade. Luwu' eventually requested help from Bone, whose sovereign in 1897 sent a large force into the highlands via Palopo, led by his son the Patta Punggawa (Bigalke 1981:49-58). These troops, mounted on horseback and armed with modern rifles, live or in Toraja folk memory as the songkok borrong or "red caps". Although we are dealing here with a far more recent historical memory, about which some Dutch records also exist, and about which Bigalke was able to gather considerable oral data in Toraja, the stories that I collected were nonetheless confusing to me, because in several instances the events of this period seemed to have become confused with those of the Arung Palakka period, so that the term "Bone war" appeared to be applied indiscriminately to a sort of fusion of the two. This merging perhaps reflects simply the fact that the stories woven around the original historical events, whatever they were, have a similar meaning to people: they all concern relations of animosity with the Bugis. In the process, much longer periods in which relations were quite good tend to be overlooked. The happenings of the 1950s, which provided an occasion for a "waking up of the oath" all over Toraja, can then be seen as climactic events resonating with the earlier ones, and creating a new form of tension in the pressure to convert to Islam. ${ }^{24}$ Some Toraja were forced to join the guerillas and did convert; at the same time there was a flood of conversions to Christianity, either as a form of resistance and the assertion of a growing sense of ethnic identity, or as a defensive move in order to avoid guerilla accusations of "paganism". Toraja were particularly alienated by the latter's killing and mutilating of their pigs, and their aggressive efforts to make rejection of the pig the central feature of conversion to Islam (Bigalke 1981:434-435). The religious attitudes of this period may be seen to contrast with those around the turn of the century. At this time, almost all the leading Toraja chiefs could speak and write Bugis, some had sent their children to the court of Sidenreng for instruction, while a few, after years of contact with Islamic élites, were even considering converting to Islam (Bigalke 1981:69, 158). For all of the disruption caused by Bugis presence in the highlands, their trading of Toraja slaves to the lowlands, and the machinations of the various Toraja chiefs who formed alliances with them, religion had not then been at issue.

Detailed and more obviously historical local memories have been preserved about the events of the late nineteenth century. These concerned not just interactions with the Bugis but also inter-village warfare. Two prominent features of these memories have to do with the seizing of rice lands by the victors, the names of particular ricefields still being remembered, and secondly (a feature also of events of the 1950s), the burning of origin-houses. Many houses in 
Saluputti were lost in these periods; during the 1950s, people were caught between the two sides, as some houses were burned by the guerillas and others by Toraja forces of the Indonesian army (Tentara Nasional Indonesia) as retribution against villages where men had joined the guerilla forces. Collecting these stories provided a number of insights into the rise and fall of fortunes of particular houses, some of which had never been rebuilt after these disasters.

A number of features may be noted about these different kinds of memory. Fentress and Wickham (1992:113-114) have commented on the way "peasant" memory generally displays certain patterns cross-culturally. One of these is "the constantly recurring importance of local geography as a structure for remembrance"; secondly, we find both "the way memories are constructed outwards" from the individual to the family and community, in relationships both amicable and hostile - memories of family feuds, for example - but also memories "that represent the community's relationship to the outside world ... the imagery of the community of resistance ... and the various imageries of the Golden Age". This memory of the community in opposition to the outside world, they suggest, "is one of the most effective recourses any social group has to reinforce its own social identity in opposition to that of others ... Its very power means that it is not always authentic". Such memories tend to be recalled more tenaciously than other, less unifying events; their social relevance remains when other, less resonant events cease to be discussed and thus become forgotten. Here, perhaps, is the means to make some sense of the recurrent memories of resistance against Bugis incursors in Toraja folk memory, and their apparent blurring and fusion of distinct historical events into a single composite image. If assertion of community and identity is the real point of the stories, their historical accuracy is not really critical. They still contain a meaningful message, and a kind of truth. The outsider may find such memories historically confusing, but as Tonkin has observed, the activity of the professional historian who tries to reconstruct "what really happened" turns out to be only "a tiny proportion of historical action and discourse in any community", and a highly specialized one at that (Tonkin 1991:121).

\section{Conclusion: Ancestors, Precedence and the Division of Meat}

Many of the mythical, genealogical and historical memories I have examined here seem to have served a dual purpose: they have helped Toraja define themselves in relation to outsiders, and at the same time have been used in determining status relations within Toraja itself. Questions of precedence, either in internal or external relations, are important in all of them. Fox (1994:99) makes the useful observation that in Austronesian societies, such issues tend to be fluid rather than fixed, and are almost always disputed or open to challenge, either because more than one point of origin can be claimed as significant, or because 
precedence can be traced in more than one way, or because significant categories used to claim precedence can be manipulated. It is crucial therefore to inquire about the social contexts in which stories or genealogies are related, and to what purpose in the present. My concluding comments concern, firstly, the amount of variation in genealogies, and disputes connected to claims about the primacy of different ancestors, and secondly, the declaiming of the names of ancestors or origin houses at funeral meat distributions, which provide a most important public setting for the reiteration and confirmation of status claims.

What kind of time frame is encompassed in people's genealogies, and how are famous ancestors related to each other chronologically? Here we encounter as much flexibility as in most of the other details. Genealogies I collected showed a depth of anywhere between five and thirty-one generations between the teller and a founding ancestor. I am fairly sure that in some cases, if I had elicited a genealogy from the same individual on two separate occasions, I would have encountered some variation. The telling itself may vary depending on the context in which it is elicited, and such variations are not necessarily perceived as critical (if they can be perceived at all, in an oral context) by the persons concerned. There is, all the same, considerable congruence in some cases; for example the two main genealogies deriving from Gonggang Sado'ko' which I collected in Malimbong, from Malle' and from Mangesa', coincide very substantially, save for the omission of a single generation, and some minor variations of birth order, attributed gender, and spelling of names. Malle"s version also retains more siblings in each generation, most of which have been dropped from Mangesa"s. This suggests rather firm memorization of a consistent tradition which may well have considerable historical content. As with any use of genealogy as a historical source, assessing how accurate a history they may contain remains a question that, in the absence of alternative sources, is impossible to resolve. ${ }^{25}$

Where variation clearly does become politically significant in the present is where questions of precedence are involved. Which particular founding ancestor came first is the subject of sometimes heated debate. Kila', for example, argues that Tangdilino' must have preceded Tamboro Langi', since his grandchild Manaek married Tamboro Langi"s son, To Mambuli Buntu; and this is widely corroborated by other genealogical accounts in which these personages occupy stable positions in relation to each other. Tato' Dena' maintains that the two men lived contemporaneously. An informant from the Saluputti district, Pak Rante Sulu', claimed that on the contrary, Tangdilino' was a descendant of Tamboro Langi', adding that in his opinion, "The most important thing now is that Ullin should be recognized as far as Goa (the old Makasar kingdom) as the most original and important tongkonan in Toraja." This claim would appear to subordinate Banua Puan to Ullin, in an effort to boost the prestige of west Toraja. Its author teaches Toraja history and culture in the relatively new Tourism Training College (Sekolah Menengah Industri Parawisata) in Ma'kale - the only school in Toraja 
in which such a subject features on the curriculum. Tangdilintin's genealogy (in Nooy-Palm [1979]) confirms Kila"s account of the relation between Tamboro Langi' and Tangdilino', while showing the founder of Kesu', Manurun di Langi' Puang ri Kesu', as appearing one generation before Tangdilino'. All such variations may be contentious and are likely to be activated, at the present time, on occasions when descendants of different houses find themselves in any situation of competition with each other.

The division and distribution of meat at funerals is a key social moment in Toraja life, one which provides a visible and material commentary, continuously revised and reiterated, on the relative social standing of the participants. It can be fraught with tension, which has on rare occasions been known to explode in physical violence where a person believes himself to have been insulted by not receiving his due. More than any other procedure, this one establishes and maintains claims to precedence. Partly, one's prestige and the size of the share to which one is entitled depends upon the "boldness" of one's own sacrifices; the more pigs and buffaloes one is known to have slaughtered, the more meat one will receive. But it is also based upon inherited rank; the recitations of the meat-divider here become a repository of historical and genealogical memory, continually kept alive in performance and having real social consequences in the present. This task has traditionally been carried out by the ritual specialists (to minaa). For a long time the Toraja Church disapproved of it as a "pagan" element of the funeral rite which Christians were supposed to dispense with, but in recent years it seems that it has become more acceptable again, and has reappeared in Christian funerals, even if not performed by a to minaa.

The meat-divider, or to mentaa, stands on top of a tall platform, the bala' kayan, and recites a chant, calling out the names of a string of founding origin houses while throwing down their shares of meat. The precise houses named will differ from area to area, and the amount of meat distributed to them depends partly on the size of the funeral and whether there is any descendant present to collect it. Since key sites such as Banua Puan and Ullin have not had a house standing on them for centuries, the meat they receive may be only a token scrap (sangkarra'). But these scraps are nonetheless important as a reaffirmation of historical links. Kila', explaining how meat dividers in the northerly Sesean area will first call out the names of Banua Puan, Kesu' and Nonongan, remarked that this practice is called untundan basse ("waking up the oath"), which he expressed in Indonesian as membangkitkan sejarah, "arousing history", in other words bringing to life the historical link traced through remote lines of descent to these famous ancestral houses. To give meat along the correct paths to one's founding tongkonan he furthermore described as umbumbun garonto' tallang, "to strengthen the base of the bamboo-culm" (rapu tallang, "a bamboo culm", with its many shoots sprouting from a single base, is also an image used to refer to a bilateral kinship grouping); such prestations are not considered to create any debt. ${ }^{26}$ An 
elderly to minaa, Ne' Roya, at Siguntu' in Sanggalangi' district, recited the opening phrases of his meat-divider's chant which names Marinding (Banua Puan), Kesu' and Nonongan as the houses of the earliest ancestors, with many poetic phrases describing their exalted status. Kesu' for example is termed sikambi' panta'nakan lolo ("guardian of the seedbed of umbilical cords"), a phrase expressive of its importance as a place of human origins. By contrast, Pak Kondo, who sometimes performs the meat division in Banga (Saluputti district) said that here, Ullin would always be first named, and might receive a large share which would be taken by any descendant from Ullin who happened to be present; next would come Mebali (the tongkonan layuk or "great house" of Banga). ${ }^{27}$

Tato' Dena', who comes from Mandetek (in Ma'kale district), explained that there are three major categories of ancestors who may be remembered in the meat division. The number of ancestral houses named depends on the size and "level" of the funeral ceremony, measured by number of buffaloes, since this affects the amount of meat available for division. Most important of all are the two ancestors associated with the spreading of the aluk, the ritual prescriptions governing Toraja life, the nene' ussio' sukaran aluk. They are Tangdilino' of Banua Puan and Tamboro Langi' (of Kandora, in this version). Secondly, there are the nene' lumion tondok, the ancestors who established the boundaries of villages. These are principally the children and later descendants of Tangdilino' and Tamboro Langi', who travelled to different places where they founded houses of their own, as recalled in genealogies. Thirdly, there are the nene' to pada tindo, the Ancestors of the Same Dream. In this area, at a five-buffalo funeral (the lowest level to qualify for the recital), Banua Puan and Kandora in the south, Ullin in the west and Sesean in the north would be named, along with Tiang, Olang and Tangsa, origin-houses closer to Mandetek. But for a very high-ranking funeral, there would be much more meat available and all of the houses of the Ancestors of the Same Dream would be named. His chant would then go on to name locally important houses such as Tadongkon, Pangi and Deata, in the immediate environs of Mandetek.

This reveals to us the social significance of the Pakila' Allo story. Although I have been unable to determine the links between that story and actual historical events in Sulawesi, I am still left with the question of how and why the tale has been so tenaciously preserved. The account given to me by Pak Pasang Kanan confirms that of Tato' Dena', for it ends by explaining that all those who trace descent from the Ancestors of the Same Dream were given the right to have the story declaimed from the top of the meat-dividing platform at their highest-ranking funerals, with shares of meat to be distributed to the descendants of each named ancestor. If this was the context in which it has traditionally been recounted, then not only did this provide a regular occasion for retelling the story, but it also gave it a meaning in terms of present social relations. The 
significance of the story must be seen to rest at least partly in its continued relevance as a means of inscribing precedence and status in Toraja society.

Local variations on the meat-divider's performance, then, provide regular occasions for the public affirmation of certain historical ties, made visible by the distribution of meat either in the form of a token gesture, or more substantial shares, which in each locality trace both distant original ancestors, and more immediate ones. The ties of descent and kinship are always connected with the locations of named houses, however much variation there may be concerning which houses are named. Names of ancestors, and of the places they settled, are recalled together and remain intermeshed.

Ten years ago, there was talk among some of the descendants of Ullin about the possibility of rebuilding that house, though it came to nothing and instead a lesser branch house has been rebuilt. Part of the thinking behind this idea was that if Ullin were to be more widely recognized as a vital origin-site, then in future more tourists might come here, particularly if (as I was told in 1994) a major new highway is to be cut through from the airport at Rantetaio, passing right over the mountain. Currently, another plan is afoot to rebuild Banua Puan in Mengkendek. This is more likely to succeed for several reasons. First, it has the backing of a very wealthy and successful Mengkendek descendant who has made a career in Jakarta. Second, there is more widespread consensus about the significance of Banua Puan as an origin-site. Almost every member of the Toraja nobility can trace descent back to this house by some means, so that in theory the huge potential number of financial contributors would mean that only small amounts would be required from each of them. The problem is to find a co-ordinator who can be fully trusted to manage these funds. Whether anyone would actually take up residence in the house is another question. It seems certain that the house, even if "brought back to life" by rebuilding, will not function in quite the traditional manner. If the plan succeeds, it would serve not just to satisfy the sense of historical pride among Mengkendek descendants of Tangdilino', but as an added draw to tour groups to pay a visit to the site, and purchase souvenirs while they are there. Some novel suggestions have already been made for its use. The Parandangan $A d a^{\prime}$ (the association representing the remaining adherents of Aluk To Dolo), has expressed a special interest in the project; one of its members proposed that the house should be run by adherents of Aluk "as a place of prayer and a site for tourism and research into Toraja history and ancestors." This is a new departure in more ways than one, not least because Aluk has never had fixed places of worship. It is clear that if this plan to resurrect the house succeeds, it will be in order to turn it to new political, economic and religious purposes, reflecting the continuing dynamic tensions between old and new in Toraja culture. 


\section{References}

Andaya, L.

1975 The nature of kingship in Bone. In A. Reid and L. Castles (eds) Pre-colonial state systems in Southeast Asia, pp.115-125. Kuala Lumpur: MBRAS Monograph no. 6.

Andi Zainal Abidin

1974 The I La Galigo epic cycle of South Celebes and its diffusion. Indonesia 17:161-169.

Basso, K.

1992 Speaking with names: language and landscape among the Western Apache. In G. Marcus (ed.) Rereading cultural anthropology, pp.220-251. Durham/London: Duke University Press.

Bender, B.

1993 Stonehenge - contested landscapes (medieval to present-day). In B. Bender (ed.) Landscape: politics and perspectives, pp.245-279. Providence/Oxford: Berg.

Bigalke, $\mathrm{T}$.

1981 A social history of "Tana Toraja", 1870-1965. PhD thesis, University of Wisconsin.

Bohannan, L.

1952 A genealogical charter. Africa 22:301-315.

Caldwell, I.

1988 South Sulawesi A.D. 1300-1600: ten Bugis texts. PhD thesis, The Australian National University.

Evans-Pritchard, E.E.

1939 Nuer time-reckoning. Africa 12:189-216.

Fentress, J. and C. Wickham

1992 Social memory. Oxford: Blackwell.

Fox, J.J.

1971a A Rotinese dynastic genealogy: structure and event. In T. Beidelman (ed.) The translation of culture, pp.37-77. London: Tavistock.

$1971 \mathrm{~b}$ Sister's child as plant: metaphors in an idiom of consanguinity. In R. Needham (ed.) Rethinking kinship and marriage, pp.219-252. London: Tavistock. 
1994 Reflections on "hierarchy" and "precedence". History and Anthropology 7(1-4):87-108.

1995 Origin structures and systems of precedence in the comparative study of Austronesian societies. Austronesian Studies August:27-57.

Hoskins, W.

1956 The making of the English landscape. London: Penguin.

Kern, R.A.

1989 I La Galigo. Yogyakarta: Gadjah Mada University Press.

Koubi, J.

1978 Il était une fois ... Lancêtre Lambe Susu, mythe Toraja sur le rapport richesse-hospitalité. Archipel 16:47-73.

1982 Rambu Solo, "La fumée descend": le culte des morts chez les Toradja du Sud. Paris: CNRS.

Küchler, S.

1993 Landscape as memory: the mapping of process and its representation in a Melanesian society. In B. Bender (ed.) Landscape: politics and perspectives, pp.85-105. Providence/Oxford: Berg.

Leach, E.

1954 Political systems of highland Burma. London: Bell.

Mattulada

1978 Pre-Islamic South Sulawesi. In H. Soebadio and C. Saarvas (eds) Dynamics of Indonesian history. Amsterdam: North-Holland.

Morphy, $\mathrm{H}$.

1993 Colonialism, history and the construction of place: the politics of landscape in Northern Australia. In B. Bender (ed.) Landscape: politics and perspectives, pp.205-243. Providence/Oxford: Berg.

Noorduyn, J.

1965 Origins of South Celebes historical writing. In Soedjatmoko (ed.) An introduction to Indonesian historiography. Ithaca: Cornell University Press.

Nooy-Palm, H.C.M.

1979 The Sadan Toraja: a study of their social life and religion. Vol. 1: Organisation, symbols and beliefs. The Hague: M. Nijhoff.

Olvig, K.

1993 Sexual cosmology: nation and landscape at the conceptual interstices of nature and culture, or what does landscape really mean? In B. Bender 
(ed.) Landscape: politics and perspectives, pp.307-343. Providence/Oxford: Berg.

Parmentier, R.

1987 The sacred remains: myth, history and polity in Belau. Chicago: University of Chicago Press.

Portelli, A.

1981 "The time of my life": functions of time in oral history. International Journal of Oral History 2/3:162-180.

Rosaldo, R.

1980 Ilongot headhunting 1883-1974: a study in society and history. Stanford: Stanford University Press.

Salombe', C.

1975 Une version orale du mythe de Sawerigading recueillie àKandora, Mengkendek, pays Toraja. Archipel 10:269-287.

Sugishima, T.

1994 Double descent, alliance, and botanical metaphors among the Lionese of Central Flores. Bijdragen tot de Taal-, Land-en Volkenkunde 150(1):146170.

Tangdilintin, L.T.

1978 Toraja dan Kebudayaannya. Rantepao: Yayasan Lepongan Bulan.

Tonkin, E.

1991 Narrating our pasts. Cambridge: Cambridge University Press.

Volkman, T.

1985 Feasts of honor: ritual and change in the Toraja Highlands. Urbana: University of Illinois Press.

Waterson, R.

1984a Rites of east and west: ritual, gender and status in Tana Toraja. In R. Waterson, Ritual and belief among the Sadan Toraja. University of Kent Centre of Southeast Asian Studies, Occasional Paper 2:3-33.

1984b Taking the place of the ancestors: ethnic identity in Tana Toraja in the 1980s. In R. Waterson, Ritual and belief among the Sadan Toraja. University of Kent Centre of Southeast Asian Studies, Occasional Paper 2:3472.

1986 The ideology and terminology of kinship among the Sadan Toraja. Bijdragen tot de Taal-, Land-, en Volkenkunde 142(1):87-112. 
1990 The living house: an anthropology of architecture in Southeast Asia. Kuala Lumpur: Oxford University Press.

1992 Using houses as history in Tana Toraja, Sulawesi (Indonesia). PAPER (People and Physical Environment Research) 39-40:15-21.

1993 Houses and life processes in island Southeast Asia: the notion of semangat and the living house. Paper presented at the Workshop on Architectural Research in Small-Scale Societies of Southeast Asia, Center for NonWestern Studies, University of Leiden, The Netherlands, 2-3 December.

White, G.

1991 Identity through history: living stories in a Solomon Islands society. Cambridge: Cambridge University Press.

Yengoyan, A.

1985 Memory, myth, and history: traditional agriculture and structure in Mandaya society. In K. Hutterer et al. (eds) Cultural values and human ecology in Southeast Asia, pp.157-176. Michigan Papers on South and Southeast Asia no. 27. University of Michigan Center for South and Southeast Asian Studies.

\section{Notes}

1 This is particularly noticeable in works on Australian Aborigines (see Morphy 1993), but has also been dealt with with great sensitivity by ethnographers in some other areas, for example Basso (1992) for the Apache of North America, or Küchler (1993) on New Ireland. For analyses of the way in which memory is bound up with place, see especially Rosaldo (1980), Yengoyan (1985), Parmentier (1987) and White (1991).

2 My fieldwork in Tana Toraja was carried out over a period of eighteen months in 1978-79 with the help of a grant from the Social Science Research Council of the United Kingdom and for nine months in 1982-83 with the aid of grants from the British Academy and the Cambridge University Evans Fund. I am very grateful to these bodies for their support, and also to LIPI, the Indonesian Institute of Sciences, who gave their permission for the research. I visited Tana Toraja again in 1994 and 1996. I should like to thank Jim Fox for his helpful criticisms of earlier versions of this paper.

3 This latter term does not have a pair to indicate the branch house. On "trunk" and "tip", and other botanical metaphors in Indonesian kinship systems, see for example Fox (1971b), Waterson (1990:124-126), and Sugishima (1994).

4 Lino': "earthquake". The name Tangdilino' means "Cannot be Shaken".

5 Published versions of the Laki Padada myth can be found in Nooy-Palm (1979:148-153) and Koubi (1982:346-358).

6 According to Christian Pelras (personal communication), the Datu or ruler of Luwu' must have some Toraja blood in order to be an acceptable candidate for office, and traditionally wears a Toraja loincloth beneath his other garments at his investiture. The Puang (or ruling noble) of Sangalla' is always invited to such ceremonies, and has the unique privilege of ordering the Datu around, while all the other nobles present must treat him (or her) with the greatest deference.

7 See Volkman (1985:22) for an example. A variety of "trickster" tales feature a hero called Dana' or Dalana'i. He is often depicted as playing outrageous tricks on fellow-villagers and even his own parents. Bua' Sarungallo of Kesu' recounted some very amusing stories in which Kesu' outwitted both Luwu' and the rival district of Ma'kale. There is a kind of continuity between these stories and those that men sometimes enjoy telling about themselves, how by their wits they outface a competitor or puncture the arrogance of a more powerful or wealthy individual. 
8 The account given here is condensed from much longer versions of the Bonggakaradeng story which I collected in 1978 from Ambe' Sora of tongkonan Rea, and Indo' Lembang, the to manakka or female priest of Tondok Tanga', both in Simbuang. Another variant, given by Mappa', the elderly headman of Balepe', concerned a hero called Pokka Linoan, and demonstrated the precedence of the district known in Dutch times as Bau, over the adjoining Bugis-inhabited area of Enrekang. In this tale, one of the sons of Pokka Linoan marries a beautiful princess of Enrekang, who gives birth to Sawerigading and his twin sister (see below).

${ }^{9}$ The sword and sheath were divided at the making of the great oath (basse kasalle) after Arung Palakka's failed invasion of Toraja in the seventeenth century (see below). The blade is said to be kept at tongkonan Paken in Simbuang. If Bugis ever again invade Toraja, the sword can be taken out and given offerings, and when pointed directly at Sawitto and with the correct spells recited over it, will stand straight up and thus "awaken the oath" (ma'tundan basse).

10 In the Tali Siba'ba story, it was her trough that turned to stone and is said to be still in Luwu'.

11 Certain orientations may be maintained partly through details of everyday practice. According to Bua' Sarungallo, it is, or was, a habit of the aristocracy of Kesu' not to eat bananas that grow on the side of the trunk facing toward Luwu'; they milk their buffaloes with their backs to Luwu', and will not drink palm wine if the tube it drips through points toward Luwu'. Similarly, I was told in Simbuang that the aristocracy there refuse to eat bananas that grow pointing toward Sangalla'. Both these cases represent the acting out of a separation from, or denial of claims to precedence by, a potentially more powerful adversary.

12 Other mythical figures in this genealogy include Bua Lolo', the daughter of Lambe' Susu (see Koubi 1978), and Suloara', the legendary first priest or to minaa from Sesean.

13 This event is further discussed below.

14 Indo' Somba's version, like that published by Salombe' (1975), retains Sawerigading's origins as the grandson of Batara Guru (the first ruler of Luwu', descended from heaven). Tato' Dena's version, on the other hand, transposed the whole story to Toraja, explaining that Sawerigading and his twin sister had appeared from no-one knew where at Tengan (Kandora). In Salombe"s version, Pindakati came from Biduk, on the slopes of Mount Latimojong. It was his second wife, Lisudai (Bug.: We Cudai) who was from Cina. This accords with Bugis versions. (It is possible that the variation is due simply to the twenty years or more that have elapsed between Salombe"s interviews and mine with the same informant (see also Portelli 1981:164).) Lack of familiarity with Bugis history and geography results in a more curious transposition. Indo' Somba was insistent that "Cina" referred to the People's Republic of China, although in fact Cina was one of the earliest Bugis chiefdoms, most probably situated at the mouth of the Cenrana River, on the border of present-day Wajo' and Bone (Caldwell 1988:207-211).

15 Interestingly, although Indo' Somba knew such a wealth of detail about the history and myths attached to the houses of Kandora, she mentioned only in passing the name of Manaek, the Datu Baine or "Female Lord" who founded tongkonan Nonongan and who is such a prominent ancestor in the Kesu' region. She mentioned a saying to the effect that the people of Kandora also traced descent from Manaek, and that this must not be forgotten or they would be struck by lightning; but she thought Manaek was a man, and her husband, Ondo Ira, was a woman; she knew little else about them. I take this as evidence of how localized even the knowledge of local experts is about matters of genealogy and myth (see Nooy-Palm 1979:153-154).

16 Fentress and Wickham (1992:82), for example, observe that "[t]here is no inherent incompatibility between memory and genealogy, or, indeed, between either of the two and true narrative history ... As a rule, oral tradition combines mythology, genealogy and narrative history rather than holding them apart." Similarly, Yengoyan (1985:172) writes of the Mandaya of the Philippines that "myth and history are combined to provide cultural coherence, which, when reproduced through time and space, articulates the past with the present." For the Mandaya, physical locations in the landscape, and also plants, particularly fruit trees planted by remembered individuals, are important mnemonic devices. Sometimes events (of past battles) will be re-enacted and sung about upon arriving at a particular clearing in the forest. As the stories are repeatedly recalled and embroidered, they become timeless. Yengoyan stresses that "the meaningfulness of these activities is not vested in the fact that they occurred in the past", and therefore "memory creates a form of history that collapses the immediate past into the present." Although Toraja do not seem to image history as forming quite the same recurrent patterns as the Mandaya do, the apparent fusion of separate events should probably not be regarded as abnormal.

17 Arung Palakka ascended the throne in 1672 and died in 1696 (Andaya 1975). Tangdilintin (1978:44) gives the date of the invasion as 1675 , which is plausible, though no evidence is offered for it. Bigalke (1981:15) follows Nooy-Palm's brief mention of Toraja resistance to an invasion by Arung Palakka 
(Nooy-Palm 1979:60), though Nooy-Palm unfortunately does not mention her sources here. Bigalke states his belief that the events described in oral memory are based on actual historical circumstances but not all Toraja today seem convinced that the king of Bone who features in the story was necessarily Arung Palakka.

18 The following summary is drawn from a complete version of this story given to me by Pak Paulus Pasang Kanan of Sangalla' in June 1996.

19 There is always the possibility that two or more oaths were sworn. Since Simbuang borders on the Bugis region of Sawitto, the part played by the Sawitto people in this war features more prominently in their memories.

20 They are not always considered to have married each other, however. As already discussed, genealogies in this area tended to show wide variation.

21 "Cuscus" and "monkeys" here refer metaphorically to buffaloes.

22 Tato' Dena' explained that after the defeat of Bone, the Ancestors of the Same Dream celebrated many rituals in order to restore harmony to the earth.

23 See Fentress and Wickham (1992:43-44) for a detailed discussion of the process of oral composition as practised by Greek, Anglo-Saxon and Serbo-Croat bards.

24 See Bigalke (1981) for a detailed account of this period.

25 That genealogies structure time in a particular way for particular kinds of kinship system, and above all serve to validate present relationships, is an insight about which anthropologists have long been in agreement (Evans-Pritchard 1939:212; Bohannan 1952:314; Leach 1954:127-128). Fox (1971a), however, has effectively demonstrated that, where alternative historical records are available, the historical information preserved in genealogies can sometimes be shown to be very considerable. Such historical depth is unfortunately missing in written records concerning Toraja, so my concern has been more with the social reality of these accounts and their continued salience in present-day political life.

26 He further commented that Christians often "forget", or do not wish to remember, to give these shares of meat, claiming that they are part of the aluk ("religious" prescriptions) rather than adat (or permissible "custom"). Christians are not supposed to employ the services of a to minaa and so the meat distribution at a Christian funeral may be carried out by someone else whose performance will not be considered complete by traditionalists. In this way, as other informants also commented, a mode of enacting historical memory is also lost.

27 Mebali is linked to Ullin by a story which attributes its founding to a daughter of Tamboro Langi'. One day while pounding rice on Mt Ullin, the sound of her pestle echoed back to her from Mebali (lit. "to answer"), so she moved to that spot and founded tongkonan Appang Bassi there. The name of this house means "iron threshold", a reference to an heirloom object apparently long since lost. 